\title{
The health equity in all policies (HEiAP) approach before and beyond the Covid-19 pandemic in the Italian context
}

\author{
R. Bucciardini , B. Contoli, P. De Castro, C. Donfrancesco, L. Falzano, R. Ferrelli, A. M. Giammarioli, B. Mattioli, \\ E. Medda, V. Minardi, G. Minelli, L. Palmieri, R. Pasetto, E. Pizzi, S. Rossi and A. Venerosi
}

For years, the scientific community has tried to promote the approach of Health Equity in All Policies (HEiAP) to policy decision-makers without having received an effective response through concrete actions; that has been the case in most countries of the world. Now, Covid-19 pandemic has not only clarified how "health" is affecting all other sectors of society and vice-versa, but it is also forcing policy makers to make important decisions, placing the concept of HEiAP at the top of the political agenda [1-4].

In the last decades many declarations and documents were elaborated with the aim of integrating health considerations with policies concerning sectors other than health, among the others The Alma-Ata Declaration of 1978, The Ottawa Charter for Health Promotion in 1986, The Tallinn Charter in 2008 and Health 2020 [5-8]. In all these documents, it is a common opinion that health depends only partly on the availability of health services, while much is related to the role of other non-health sector policies (development and employment, poverty, environment, school and education, social protection and security).

During the Covid-19 pandemic, we are experimenting with one of the most important concepts underlying the HEiAP approach: How policy decisions affect health and health systems, including the distribution of health and equity in health systems. Despite the widespread literature that warned us about a possible pandemic, the health systems have not equipped in time to deal with this pandemic [9-11].

\footnotetext{
* Correspondence: raffaella.bucciardini@iss.it

Istituto Superiore di Sanità, Viale Regina Elena 299, 00161 Roma, Italy
}

If we consider the Italian spread of the pandemic there is an important gap in its health system that should be noted. In Italy, healthcare is provided to all citizens and residents by a national health coverage [12]. In 2000, Italy's healthcare system was regarded as the second best in the world (after France) by the World Health Organization (WHO) $[13,14]$. In the last years, Italy's healthcare system has undergone some important changes $[15,16]$. One of these changes regards regions gaining a considerable autonomy in determining the macrostructure of their health systems. Moreover, Italian regions have experienced a significant trend to promote the private sector (e.g. in most northern regions, including Lombardy, the region most affected by the pandemic) [17-19]. Concurrently, public hospitals have been merged, closed or heavily downsized. In addition, there has been a growing lack of decentralization of care, which could instead be very helpful in reducing the workload for hospitals. The pandemic has shown how much our healthcare system still relies primarily on hospitals and how much the territorial health system needs to be strengthened. In fact, while managing the emergency, hospital care should have been assisted more by local assistance. Furthermore, the accessibility and functionality of local health services are extremely different among regions $[9,12]$. These choices have led to a lack of harmonization of best practices and sharing of standardized clinical with a loss of central control by the Government. At the same time, there have been severe cuts to the health system funding and lack of replacement of health workers [20]. Because of these political decisions, the Italian health system was unprepared to face a pandemic. In this context, the vulnerable and fragile people are often the most affected ones. Most of the

\section{$\triangle B M C$}

(c) The Author(s). 2020 Open Access This article is licensed under a Creative Commons Attribution 4.0 International License, which permits use, sharing, adaptation, distribution and reproduction in any medium or format, as long as you give appropriate credit to the original author(s) and the source, provide a link to the Creative Commons licence, and indicate if changes were made. The images or other third party material in this article are included in the article's Creative Commons licence, unless indicated otherwise in a credit line to the material. If material is not included in the article's Creative Commons licence and your intended use is not permitted by statutory regulation or exceeds the permitted use, you will need to obtain permission directly from the copyright holder. To view a copy of this licence, visit http://creativecommons.org/licenses/by/4.0/ The Creative Commons Public Domain Dedication waiver (http://creativecommons.org/publicdomain/zero/1.0/) applies to the data made available in this article, unless otherwise stated in a credit line to the data. 
victims have been elderly people with pre-existing unhealthy conditions. Moreover, due to overcrowding of hospitals, people with mild symptoms are quarantined at home. In this scenario, people living in small apartments and having lower living standards find it difficult to be adequately isolated from other members of the family to prevent contagion. In the same way, the most fragile people including those who live with mental ill health and isolation can exacerbate existing health problems [21]. Furthermore, we are experiencing a dramatically sudden evolution in vulnerabilities in the era of Covid-19 [22]. These groups can change or increase because of the side effects of the Covid-19 pandemic, such as those related to the loss of work or income, which means reducing opportunities of wellbeing and increasing the risk of unhealthy behaviours associated with unemployment or the lack of material resources. The loss of work and/or income is one of the major consequences of Covid-19. The International Labour Organization estimates that around 436 million enterprises in the hardest-hit sectors worldwide are currently facing high risks of serious disruption [23]. In Italy, the Ministry of Economy estimates a loss of workplaces of $2.1 \%$ in 2020 [24].

Similarly, the negative consequences of choices made in other non-health sectors are emerging dramatically during the pandemic. In Italy, the closure of schools due to the pandemic has highlighted some important gaps and fragility of the education system. As we know, education level can be considered one of the main social determinants of health. Despite this fact, interventions such as providing all students with adequate equipment to be able to study, in particular a computer and an internet connection have not been implemented. The education sector has been severely impacted by the COVID-19 pandemic for the lack of a digital system as well. Many teachers, students and families are for the first time grappling with the task of conducting online classes and remote learning, in the confinement of their homes. During the Covid-19 pandemic, we are dramatically experiencing how these social inequalities are turning into health inequalities, at global level. It is true that 2019-2020 coronavirus pandemic was not predicted, at least not by policy makers, but it is now highlighting how the HEiAP approach has not been introduced into the educational sector (providing all students with all the necessary tools to guarantee an adequate level of education for everyone is a fundamental prerequisite for assuring everyone the same protection against not getting sick or dying) [25-28].

Another important aspect that is emerging is related to the social position. Indeed, people with a more fragile social position suffer from the devastating effects of a pandemic. Once again, the pandemic is highlighting how the social position can indirectly affect health. In fact, the most economically fragile people (caregivers, housekeepers, precarious workers and all those who do not have adequate socio-economic protection) are those that will most likely have serious repercussions in terms of health implications even in the long run $[25,29]$.

In this scenario, promoting a sustainable development model based on an integrated approach of the several dimensions of development, from environmental to social and economic ones, is at the basis of the 2030 Agenda for United Nations Sustainable Development Goals (SDGs) [30, 31]. It is also important to highlight, after the lesson learnt from the Covid-19 pandemic, that Goal 3 "Good Health and Well-Being" should be now placed at the center of the Agenda and other global health models founded on intersectoral actions should be thought, as already underlined for responding to the widespread environmental degradation [32]. If before the pandemic, the understanding and mapping of important interactions among goals, sometimes, seemed to represent a theoretical exercise, now concrete actions should be implemented. In this context, a key objective of HEiAP is to aid informed policy makers. When different policy sectors are in competition, it is crucial that policy decision-makers are informed about these matters, taking into consideration any kind of implications on health and equity, supported by scientific evidence, and expressed in a way that they can easily understand.

An important component of this process is to define a strategy for an action plan and establish an evaluation framework and monitoring mechanism. Specific tools, indicators and analyses providing evidence-based data on how public policies and interventions impact health-related outcomes and health systems, as well as the distribution of these impacts across various population groups, should be considered. The results should be used to provide information and evidence from a health policy perspective at government level.

In this context, collaboration between all health and non-health stakeholders is essential and it is also necessary to strengthen the role of the health sector with stewardship.

With the purpose of promoting the HEiAP approach and with the SDGs vision guiding its activity, the main Italian research institute for public health - Istituto Superiore di Sanità (ISS), Italian National Institute of Health, the technical and scientific body of the Italian $\mathrm{Na}-$ tional Health Service - has recently established a crossdisciplinary Unit involving researchers from different backgrounds [33]. Thanks to the ISS organization, including multidisciplinary expertise, the HEiAP approach has 
become part of its institutional Agenda with the main goal of promoting the inclusion of health considerations in all policies and advocating their effective implementation across sectors in order to maximize health benefits.

This commitment aims to guarantee scientific evidence able to support and drive policies and actions and improve Italy's role within the European panorama in terms of HEiAP approach acting on SDGs.

\section{Authors' contributions}

All Authors contributed in equal part to the design and production of the manuscript, sharing each one of its phases (design, writing, commenting, reviewing, final editing).

\section{Competing interests}

The authors declare that they have no competing interests.

Received: 11 May 2020 Accepted: 2 June 2020

Published online: 08 June 2020

\section{References}

1. Brown C, Harrison D, Burns H, Ziglio E. Governance for health equity taking forward the equity values and goals of health 2020 in the WHO European region. Copenhagen: World Health Organization; 2013. Available at: http:// www.euro.who.int/data/assets/pdf_file/0020/235712/e96954.pdf.

2. Commission on Social Determinants of Health. Closing the gap in a generation: health equity through action on the social determinants of health. Final Report of the Commission on Social Determinants of Health. Geneva: World Health Organization; 2008. Available at: http://apps.who.int/ iris/bitstream/handle/10665/43943/9789241563703_eng.pdfijsessionid=226 CF679D645D69D82584028E8FCF6C7? sequence=1.

3. Vågerö D, Illsley R. Explaining health inequalities: beyond black and barker: a discussion of some issues emerging in the decade following the black report. Eur Sociol Rev. 1995;11(3):219-41.

4. Wang Z, Tang K. Combating COVID-19: health equity matters. Nat Med. 2020;26:458-64. www.nature.com/naturemedicine.

5. World Health Organization. Declaration of Alma-Ata. International Conference on Primary Health Care. Alma-Ata: USSR; 1978. p. 6-12. https:// www.who.int/publications/almaata_declaration_en.pdf.

6. World Health Organization. Ottawa charter for health promotion. First International Conference on Health Promotion. Ottawa; 1986. p. 17-21. http://www.euro.who.int/_data/assets/pdf_file/0004/129532/Ottawa_ Charter.pdf?ua=1.

7. World Health Organization. The Tallinn Charter: Health Systems for Health and Wealth. Tallin; 2008. p. 25-7. http://www.euro.who.int/_data/assets/ pdf file/0008/88613/E91438.pdf?ua=1.

8. World Health Organization. Health 2020: the European policy for health and well-being. http://www.euro.who.int/en/health-topics/health-policy/health-2 020-the-european-policy-for-health-and-well-being/about-health-2020,

9. Nacoti M, Ciocca A, Giupponi A, Brambillasca P, Lussana F, Pisano M, Goisis G, Bonacina D, Fazzi F, Naspro R, Longhi L, Cereda M, Montaguti C. At the epicenter of the Covid-19 pandemic and humanitarian crises in Italy: changing perspectives on preparation and mitigation. NEJM Catalyst Innov Care Delivery. 2020. https://doi.org/10.1056/CAT.20.0080.

10. Peter Daszak. We Knew Disease X Was Coming. It's Here Now. The New Times.; 2020 Available at: https://www.nytimes.com/2020/02/27/opinion/ coronavirus-pandemics.html.

11. Annual review of diseases prioritized under the R\&D Blueprint; 2018. Available at: http:/origin.who.int/emergencies/diseases/2018prioritizationreport.pdf.

12. Law 833/1978 Establishment of the National Health Service. Available at: https://www.mindbank.info/item/3702.

13. "The World Health Organization's ranking of the world's health systems". Photius.com. Retrieved 2015-09-07.

14. WHO. The World health report 2000: health systems: improving performance. Geneva: World Health Organisation press. Available at: https:// www.who.int/whr/2000/en/.

15. Ermeneia - Studi \& Strategie di Sistema, AIOP - Associazione Italiana Ospedalità Privata. Health \& Hospitals in Italy. 16th Annual report 2018.
Franco Angeli; 2019. ISBN 978-88-917-7242-8. http://ojs.francoangeli.it/_ omp/index.php/oa/catalog/book/399.

16. Ferré F, de Belvis AG, Valerio L, Longhi S, Lazzari A, Fattore G, Ricciardi W, Maresso A. Italy: health system review. Health Syst Trans. 2014;16(4):1-168.

17. Armocida B, et al. The Italian health system and the COVID-19 challenge. Lancet Public Health. 2020;5(5):e253.

18. Sartor M. E. La nebbia sulla sanità privata in Lombardia. Salute Internazionale, 2019. https://www.saluteinternazionale.info/2019/06/lanebbia-sulla-sanita-privata-in-lombardia/.

19. Sartor M. E. Sanità lombarda: domande in cerca di risposta. Salute Internazionale, 2019 https://www.saluteinternazionale.info/2019/07/sanitalombarda-domande-in-cerca-di-risposta/.

20. Paterlini M. Italy's health system reforms on hold. Lancet. 2013;381(9872): 1085-6.

21. Chung RY-N, Dong D, Li MM. Socioeconomic gradient in health and the covid-19 outbreak. BMJ. 2020;369:m1329. https://doi.org/10.1136/bmj.m1329 Published 1 April 2020

22. Redefining vulnerability in the era of COVID-19. Lancet. 2020;395(10230): 1089. https://doi.org/10.1016/S0140-6736(20)30757-1.

23. ILO Monitor: COVID-19 and the world of work. Third edition. Updated estimates and analysis https://www.lo.org/wcmsp5/groups/public/\%2D\%2 D-dgreports/\%2D\%2D-dcomm/documents/briefingnote/wcms 743146.pdf.

24. Italian Ministry of Economy. Document of Economy and Finance 2020. Available at: http://www.dt.mef.gov.it/modules/documenti it/analisi_ progammazione/documenti_programmatici/def_2020/DEF_2020_Sez-IProgramma_di Stabilitx.pdf.

25. Kroger H, Pakpahan E, Hoffmann R. What causes health inequality? A systematic review on the relative importance of social causation on health selection. Eur J Pub Health. 2015;25(6):951-60

26. Smith JP. The impact of childhood health on adult labor market outcomes. Rev Econ Stat. 2009:91(3):478-89.

27. Mackenbach JP, Stirbu I, Roskam AJ, Schaap MM, Menvielle G, Leinsalu M, et al. Socioeconomic inequalities in health in 22 European countries. New England J Med. 2008;358(23):246881.

28. Galobardes B, Lynch J, Smith GD. Measuring socioeconomic position in health research. Br Med Bull. 2007;81-82:21-37.

29. Macintyre S. The black report and beyond: what are the issues? Soc Sci Med. 1997;44(6):723-45.

30. UN Agenda 2030 - Council of Europe. https://www.coe.int/en/web/ programmes/un-2030-agenda.

31. Alleanza Italiana per lo Sviluppo Sostenibile (ASviS). L'ttalia e gli Obiettivi di Sviluppo Sostenibile. Rapporto ASviS 2019. Available at: https:/asvis.it/ public/asvis2/files/REPORT_ASvis_2019.pdf.

32. Hussain S, Javadi D, Andrey J, Ghaffar A, Labonté R. Health intersectoralism in the sustainable development goal era: from theory to practice. Glob Health. 2020;16(1):15. https://doi.org/10.1186/s12992-020-0543-1).

33. Bucciardini R, Ferrelli RM, Giammarioli AM, et al. Health inequalities: a research positioning exercise at the National Institute of health, Italy. EJPH. 2019. https://doi.org/10.1093/eurpub/ckz115.

\section{Publisher's Note}

Springer Nature remains neutral with regard to jurisdictional claims in published maps and institutional affiliations.

Ready to submit your research? Choose BMC and benefit from

- fast, convenient online submission

- thorough peer review by experienced researchers in your field

- rapid publication on acceptance

- support for research data, including large and complex data types

- gold Open Access which fosters wider collaboration and increased citations

- maximum visibility for your research: over $100 \mathrm{M}$ website views per year

At BMC, research is always in progress.

Learn more biomedcentral.com/submissions 